\title{
In vitro activation of rainbow trout macrophages stimulates inhibition of Renibacterium salmoninarum growth concomitant with augmented generation of respiratory burst products
}

\author{
L. J. Hardie ${ }^{1, *}$, A. E. Ellis ${ }^{2}$, C. J. Secombes ${ }^{1, * *}$ \\ 'Department of Zoology, University of Aberdeen, Tillydrone Avenue, Aberdeen AB9 2TN, United Kingdom \\ ${ }^{2}$ SOAEFD Marine Laboratory, PO Box 101, Victoria Road, Aberdeen AB9 8DB, United Kingdom
}

\begin{abstract}
Rainbow trout head kidney macrophages pretreated for $48 \mathrm{~h}$ with a supernatant which contained macrophage activating factor (MAF) obtained from Concanavalin A/phorbol myristate acetate stimulated rainbow trout leucocytes express an enhanced ability to inhibit Renibacterium salmoninarum growth in vitro compared with untreated controls. Enhanced 'killing' capacity of these macrophages was detectable after $24 \mathrm{~h}$ exposure to $R$. salmoninarum in vitro. Addition of $\mathrm{N}^{\mathrm{G}}$-methyl$\mathrm{L}$-arginine in vitro did not diminish bacterial growth inhibition by MAF-activated macrophages, suggesting that nitric oxide radicals were not involved in this event. However, MAF-treated macrophages expressed enhanced respiratory burst activity compared with control macrophages after a $3 \mathrm{~d}$ exposure to $R$. salmoninarum in vitro. In addition, it was demonstrated that $R$. salmoninarum was susceptible to hydrogen peroxide $\left(\mathrm{H}_{2} \mathrm{O}_{2}\right)$ in vitro using a cell-free assay. Introduction of catalase to the in vitro macrophage assay abrogated the 'killing' activity, suggesting that $\mathrm{H}_{2} \mathrm{O}_{2}$ release from activated macrophages was involved in the inhibition of $R$. salmoninarum growth. The results are discussed in relation to other intracellular pathogens and the possible importance of cell-mediated immunity for protection against bacterial kidney disease.
\end{abstract}

KEY WORDS: Renibacterium salmoninarum - Macrophage activation - Respiratory burst Growth inhibition

\section{INTRODUCTION}

Bacterial kidney disease (BKD), induced by the Gram-positive bacillus Renibacterium salmoninarum, is a significant infection of cultured and feral salmonids (Evelyn 1993). The disease is typically slowly progressive and systemic, characterised by renal and muscular granulomata, abdominal ascites, internal haemorrhage and anaemia. The bacillus is able to survive within cells of the mononuclear phagocyte system (Young \&

\footnotetext{
- Present address: Rowett Research Institute, Greenburn Road, Bucksburn, Aberdeen AB2 9SB, United Kingdom

- Addressee for correspondence.

E-mail: c.secombes@abdn.ac.uk

Chapman 1978), a scenario reminiscent of several bacterial (Dannenberg 1991, Baldwin et al. 1993) and parasitic infections in mammals (Liew \& Cox 1991). This intracellular strategy may afford protection from extracellular mechanisms of host defence, including antibody binding and complement fixation. Indeed, this may account for the lack of protection conferred by many $R$. salmoninarum antigen preparations although they stimulate elevated agglutinin levels in salmonids (Baudin Laurencin et al. 1977, Evelyn 1993). Furthermore, opsonization of $R$. salmoninarum with specific antisera and complement significantly enhances their survival and growth following phagocytosis by normal rainbow trout macrophages (Bandin et al. 1995). Access to intracellular sites by pathogens often in- 
volves mimicry of recognition molecules such as selectins and integrins (Sandros \& Tuomanen 1993) or fixation of complement to induce phagocytosis via complement receptors (Kaufmann 1993). In this way cellular defences may be subverted, since phagocytosis by these ligands does not trigger bactericidal pathways such as the release of toxic reactive oxygen radicals, and once intracellular, pathogens may further thwart host defences by preventing phagolysosomal fusion or by entering the cytosol (Baldwin et al. 1993). It is presumed that $R$. salmoninarum must employ similar tactics. The bacterium is known to activate the alternative complement pathway with subsequent covalent binding of $\mathrm{C} 3 \mathrm{~b}$, and this enhances phagocytosis by trout macrophages in vitro (Rose \& Levine 1992).

In mammals, intracellular pathogens such as Ehrlichia spp. and Leishmania spp. can be eliminated through experimental upregulation of cell-mediated immune responses (Liew el di. i990, Park \& Rikinisa 1992). Particular cytokines appear to play pivotal roles as paracrine or autocrine modulators of macrophage function in resistance to various intracellular pathogens and include interferon (IFN) $-\gamma_{\text {, tumor necrosis }}$ factor (TNF) $-\alpha$ and interleukins (IL) 1 and 6 (Titus et al. 1991, Nauciel \& Espinasse-Maes 1992, Denis \& Ghadirian 1994). Typically, these cytokines upregulate phagocyte cytocidal pathways, including the release of toxic reactive oxygen and nitrogen species (Ding et al. 1988, Thomson 1991). In fish, it is known that salmonid phagocyte functions can be upregulated experimentally in vitro using supernatants from antigen or mitogen stimulated leucocytes, which are thus deemed to contain a macrophage activating factor (MAF) (Graham \& Secombes 1988, Marsden et al. 1994). MAF treatment of macrophages results in elevated bactericidal activity against Aeromonas salmonicida, probably as a result of elevated exposure to toxic $\mathrm{H}_{2} \mathrm{O}_{2}$ species (Sharp \& Secombes 1993). However, evidence is growing to support the notion that nitric oxide synthase is present in teleosts (Schober et al. 1993, Hardie et al. 1994b, Schoor \& Plumb 1994, Wang et al. 1995) and thus nitrogen radicals may also have a protective role to play in disease elimination in these animals.

Salmonid macrophages do show a weak capacity to inhibit Renibacterium salmoninarum growth in vitro when cultured together for 5 or more days, although the mechanism for this elimination is not understood. (Bandín et al. 1992). Therefore, the aim of this study was to ascertain whether the cellular immune response in salmonids may potentially afford protection to $R$. salmoninarum through upregulation of phagocyte functions by cytokines. To this end, MAF-containing supernatants were examined for their ability to upregulate rainbow trout macrophage-mediated inhibition of $R$. salmoninarum growth in vitro. This was demonstrated after a $7 \mathrm{~d}$ culture period with bacteria, known to be sufficient time to allow some inhibition by normal macrophages (Bandín et al. 1992), and after a 1 d coculture period, previously shown to be insufficient time for growth inhibition. The potential mechanisms of this phenomenon were also investigated.

\section{MATERIALS AND METHODS}

Fish. Rainbow trout Oncorhynchus mykiss weighing 300 to $500 \mathrm{~g}$ were obtained from College Mill trout farm, Almond Bank, Perthshire, UK. Fish were acclimated to $14^{\circ} \mathrm{C}$ in aerated, dechlorinated mains water and fed twice daily on commercial trout peliets (EWOS) for at least 2 wh before use

Preparation of head kidney macrophage monoiayers. Phagocyte-enriched head kidney leucacyte suspensions were obtained as previously described (Secombes 1990). Briefly, head kidney leucocyte suspensions were prepared in heparinized Leibovitz medium (L15, Gibco) and separated on a $34 \% / 51 \%$ discontinuous Percoll density gradient. The phagocyte-enriched fraction was collected from the interface, washed twice in L15 and resuspended to $2 \times 10^{7}$ viable cells $\mathrm{ml}^{-1}$ in $\mathrm{L} 15$ containing $0.1 \%$ foetal calf serum (FCS, GibCo). Aliquots (100 $\mu$ l) of this suspension were dispensed into wells of a 96 well microtitre plate (Nunc). After $3 \mathrm{~h}$ at $18^{\circ} \mathrm{C}$, non-adherent cells were washed off with L15 medium. The remaining macrophage monolayers were incubated with $100 \mu \mathrm{l}$ L15 plus $5 \%$ FCS and washed again with this medium before use. All solutions were antibiotic-free.

Production of MAF supernatants. A MAF supernatant was produced using the method of Graham \& Secombes (1988), with the exception that antibiotics were excluded from this protocol to avoid effects on subsequent bactericidal assays (see below). Briefly, head kidney leucocytes obtained from a rainbow trout were stimulated with mitogens $(10 \mu \mathrm{g}$ Concanavalin A ml-1 plus $5 \mu \mathrm{g}$ phorbol myristate acetate $\mathrm{ml}^{-1}$, Sigma) for $3 \mathrm{~h}$. After thorough washing, treated cells were cultured in L15 plus $10 \%$ FCS for a further $48 \mathrm{~h}$ before the supernatant was harvested.

The presence of MAF activity in the supernatant was confirmed by its ability to augment respiratory burst activity of test macrophages in vitro as assessed by the ferricytochrome $c$ reduction technique (see below). Optimal stimulatory effects were observed at a 1:4 dilution of the supernatant (data not shown), and subsequent macrophage stimulations used this concentration of MAF.

Bacteria. A strain of Renibacterium salmoninarum (MT426) originally isolated from a clinical outbreak of 
BKD in rainbow trout in Scotland was obtained from the SOAEFD Marine Laboratory culture collection. This isolate expressed characteristics associated with virulence (Bruno 1988), including an autoaggregating capacity and the presence of the surface-associated p57 protein as ascertained by SDS-PAGE (data not shown). Bacteria were cultured on Mueller Hinton Agar (Difco) supplemented with $0.1 \%$ L-cysteine hydrochloride for $7 \mathrm{~d}$ at $15^{\circ} \mathrm{C}$. Bacteria were washed off the agar with L15 medium, washed twice, counted and then serially diluted in L15 plus 5\% FCS or phenol-red-free Hanks' balanced salt solution (HBSS, Gibco) for bactericidal or cell free assays, respectively (see below). Before bactericidal assays, FCS was screened to confirm that there were no deleterious effects on $R$. salmoninarum growth in vitro.

Co-culture assays. These assays are based upon procedures previously described (Graham et al. 1988, Bandín et al. 1992). Macrophage monolayers from 3 fish per experiment, either untreated or pretreated for $48 \mathrm{~h}$ with $\mathrm{MAF}$, were washed twice with $\mathrm{L} 15$ before the addition of $50 \mu \mathrm{L}$ L15 plus $5 \%$ FCS. Macrophage monolayers which had been washed and lysed with $50 \mu \mathrm{l}$ cold sterile distilled water served as controls. A volume of $50 \mu \mathrm{l}$ of Renibacterium salmoninarum suspended in L15 plus 5\% FCS was then added to macrophage monolayers in triplicate to give concentrations ranging from 0.25 to $2 \times 10^{7}$ bacteria well ${ }^{-1}$. In addition, various micromolar concentrations of $\mathrm{N}^{\mathrm{G}}$-methyl-L-arginine (L-NMMA, Sigma) were added to some wells to inhibit putative nitric oxide synthase activity (Wang et al. 1995). Furthermore, $0.3 \mathrm{mg}$ catalase $\mathrm{ml}^{-1}$ (Sigma) was introduced in some wells to degrade hydrogen peroxide $\left(\mathrm{H}_{2} \mathrm{O}_{2}\right)$ produced during the in vitro assay. Throughout, reagents were diluted in appropriate media and added to give a constant final volume of $200 \mu \mathrm{l} \mathrm{well} \mathrm{l}^{-1}$ across all treatments.

Microtitre plates were then centrifuged for 5 min at $150 \times g$, to aid contact between bacteria and macrophages. After a period of 1 or $7 \mathrm{~d}$ at $18^{\circ} \mathrm{C}$, infected cultures were again centrifuged at $150 \times g$, the supernatant aspirated, and $50 \mu \mathrm{l}$ of cold sterile distilled water added, which effectively lysed the macrophages, releasing any intracellular bacteria. A volume of $100 \mu \mathrm{l}$ of L 15 containing $5 \%$ FCS was added to all wells, and plates which had only been exposed to macrophages for $1 \mathrm{~d}$ were given a $6 \mathrm{~d}$ 'grow up' period so that the relationship between macrophage exposure time and bacterial level could be assessed at a fixed and therefore comparable time point. In addition, because of the lower starting concentrations of bacteria used and the slow in vitro doubling time of Renibacterium salmoninarum, the $6 \mathrm{~d}$ grow up period was required to permit the bacteria to reach concentrations within the detection range of the assay. Thus, after a total of $7 \mathrm{~d}$ in vitro for all cultures, bacterial viability was quantified by the addition of $10 \mu l$ 3-(4,5-dimethylthiazol-2-yl)-2,5diphenyltetrazolium bromide (MTT, $5 \mathrm{mg} \mathrm{ml}^{-1}$; Sigma) per well. The optical density $(600 \mathrm{~nm})$ of each well was assessed after exactly 15 min using a multiscan spectrophotometer (MDC). In some instances (the catalase co-culture experiment) data were expressed as a percentage of the values obtained using untreated macrophages.

Cell-free generation of oxygen radicals. To determine the susceptibility of Renibacterium salmoninarum to oxygen radical species a photochemical radical-generating system was employed (Karczewski et al. 1991). In this system $R$. salmoninarum were exposed to levels of oxygen radicals, such as superoxide anion (approx. $7 \mathrm{nmol}$ well ${ }^{-1}$ ), consistent with quantities that might be generated from MAF-activated macrophages in vitro (Jang et al. 1994). Briefly, washed $R$. salmoninarum were serially diluted in phenol-red-free HBSS containing $12.5 \mathrm{mM}$ methionine and $0.1 \mathrm{mM}$ riboflavin. Aliquots $(100 \mu \mathrm{l})$ were then dispensed into wells to give a range of $1.6 \times 10^{5}$ to $10^{8}$ bacteria well ${ }^{-1}$. Catalase $\left(0.3 \mathrm{mg} \mathrm{m}^{-1}\right.$ ) or superoxide dismutase (SOD,

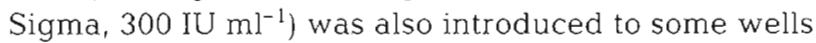
to degrade any generated hydrogen peroxide or superoxide radicals, respectively. The riboflavin was then photoreduced by a $5 \mathrm{~min}$ exposure to a $21 \mathrm{~W}$ light source with a Kodak no. 47 blue filter (360 to $520 \mathrm{~nm}$ ) at a range of $7 \mathrm{~cm}$, the methionine serving as a hydrogen donor. Following this, the plates were incubated for $5 \mathrm{~h}$ at room temperature in natural light to support further radical generation, then centrifuged at $150 \times g$ for $5 \mathrm{~min}$ and the supernatant carefully removed. Finally, $100 \mu \mathrm{l}$ of L15 plus $5 \%$ FCS was added per well to support $R$. salmoninarum growth for the next $7 \mathrm{~d}$ at $18^{\circ} \mathrm{C}$. Bacterial growth was assessed by MTT reduction as outlined above.

Respiratory burst activity. Macrophage monolayers, some of which had been pretreated for $48 \mathrm{~h}$ with MAF, were washed twice with $\mathrm{L} 15$ before the addition of Renibacterium salmoninarum at concentrations ranging from $2.5 \times 10^{6}$ to $3.2 \times 10^{8}$ bacteria in $100 \mu \mathrm{L} \mathrm{L} 15$ plus $5 \%$ FCS. The microtitre plates were then centrifuged for $5 \mathrm{~min}$ at $150 \times g$ to aid contact between bacteria and macrophages. After $3 \mathrm{~d}$ at $18^{\circ} \mathrm{C}$, infected cultures were centrifuged and the supernatant aspirated. The plates were carefully washed twice with phenol-red-free HBSS, using centrifugation and aspiration steps. To each well, $100 \mu \mathrm{l}$ HBSS containing ferricytochrome $c$ ( $2 \mathrm{mg} \mathrm{ml}^{-1}$, Sigma) and phorbol myristate acetate ( $1 \mu \mathrm{g}$ $\mathrm{ml}^{-1}$ ) was then added to stimulate the respiratory burst. As a control for specificity, $300 \mathrm{IU}$ SOD ml-1 was added to some wells. The optical density of each well was measured at $550 \mathrm{~nm}$ after 30 min using a multiscan spectrophotometer, with the relevant SOD control act- 
ing as the blank. Optical densities were converted to nmol $\mathrm{O}_{2}^{-}$produced, as described by Pick (1986), i.e. by multiplying by a factor of 15.87 .

Statistics. Data were analysed using 1- and 2-way analysis of variance (ANOVA), and Student's t-test.

\section{RESULTS}

The results show that macrophages pretreated with a MAF supernatant for $48 \mathrm{~h}$ express a markedly enhanced $(\mathrm{p}<0.001)$ ability to inhibit in vitro growth of Renibacterium salmoninarum across all bacterial concentrations tested, compared with untreated counterparts, when incubated with the bacteria for $7 \mathrm{~d}$ (Fig. 1). Untreated macrophages did not show this activity compared with lysed macrophage controls. Indeed, bacterial growth was significantly higher $(p<0.001)$ in the iniact macrophage group compared with the lysed control. The effectiveness of MAF pretreatment of macrophages was clear even after only $24 \mathrm{~h}$ of contact between cells and bacteria (Fig. 2), as determined overall by 2 -way ANOVA $(\mathrm{p}<0.01)$. Indeed, with the exception of the highest bacterial concentration, the other bacterial concentrations showed typically that MAF pretreatment of macrophages resulted in a significant $(p<0.05)$ reduction in bacterial growth, although clearly not to the same degree as that seen after a $7 \mathrm{~d}$ co-culture period. The inclusion of L-NMMA in vitro did not diminish the effect of MAF-activated

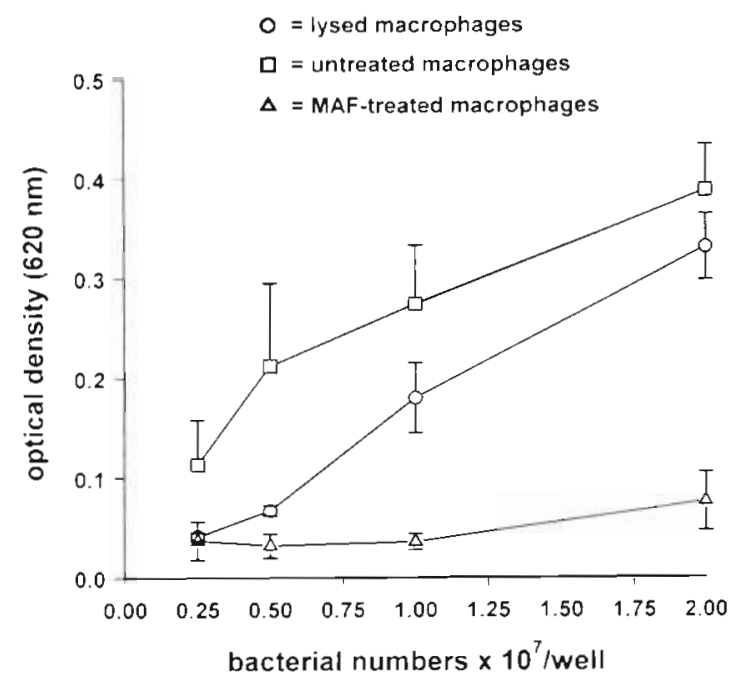

Fig. 1 Effect of $7 \mathrm{~d}$ co-culture between rainbow trout macrophages and varying concentrations of Renibacterium salmoninarum on bactenal growth in vitro, as measured by MTT reduction (optical density $620 \mathrm{~nm}$ ). In some instances macrophages were pretreated with MAF-containing supernatants for $48 \mathrm{~h}$ before use, or were lysed immediately before the assay. Data are means $( \pm \mathrm{SE}$ ) of triplicate fish

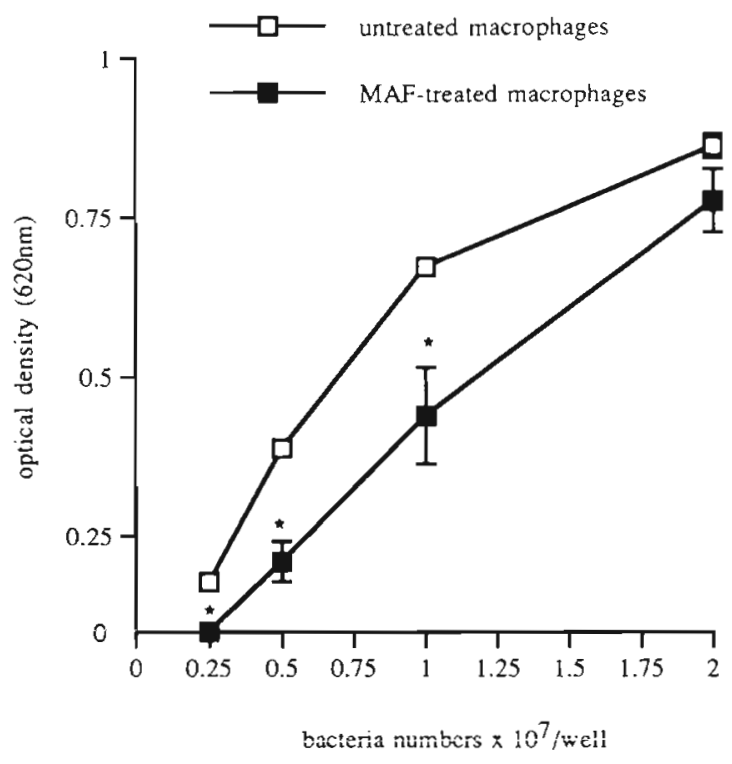

Fig. 2. Effect of $24 \mathrm{~h}$ co-culture between rainbow trout macrophages and varying concentrations of Renibacterium salmoninarum on bacterial growth in vitro, as measured by the reduction of MTT (optical density $620 \mathrm{~nm}$ ). Growth was assessed after lysis of the macrophages and a further $6 \mathrm{~d}$ 'grow up' period, as described in the 'Materials and methods' In some instances macrophages were pretreated with MAFcontaining supernatants for $48 \mathrm{~h}$ before use. Data are means $( \pm$ SE) of triplicate wells of macrophages from a single fish and are representative of 3 similar experiments. ${ }^{\star} p<0.05$ compared with untreated macrophages at the same bacterial concentration

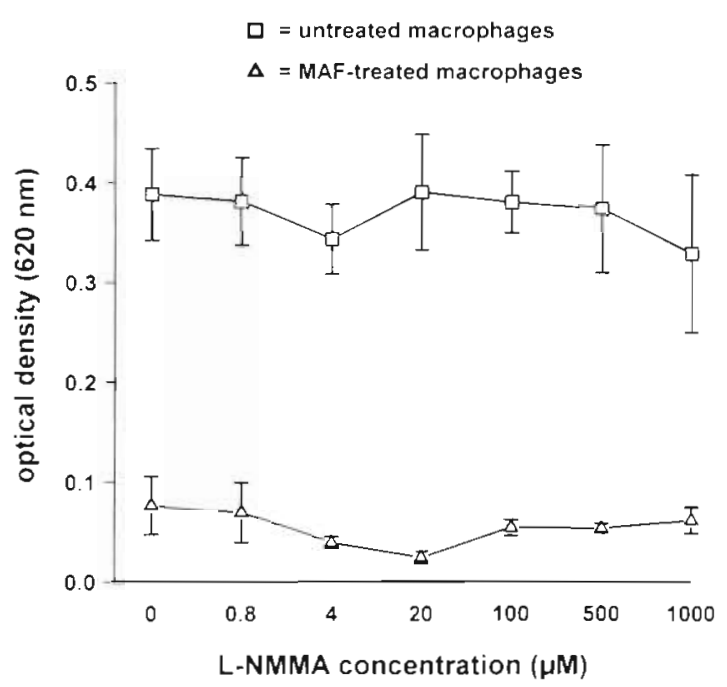

Fig. 3. Effect of varying concentrations of L-NMMA on the growth inhibition of Renibacterium salmoninarum (at $2 \times 10^{7}$ bacteria well ${ }^{-1}$ ) by untreated and MAF-treated macrophages during a $7 \mathrm{~d}$ co-culture in vitro, as measured by $\mathrm{MT}^{-} \mathrm{T}$ reduction (optical density $620 \mathrm{~nm}$ ). Data are means ( $\pm \mathrm{SE}$ ) of triplicate fish 


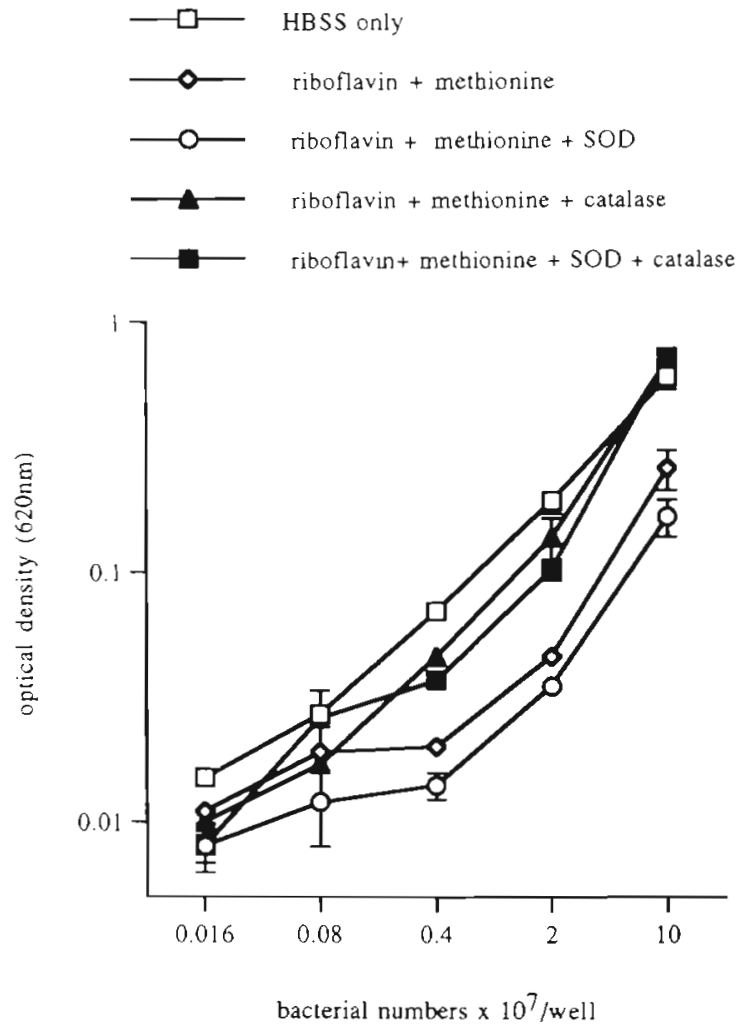

Fig. 4. Effect of a $5 \mathrm{~h}$ exposure to chemically generated oxygen radicals on the in vitro growth of varying concentrations of Renibacterium salmoninarum. In some wells superoxide dismutase (SOD, $300 \mathrm{IU} \mathrm{ml}^{-1}$ ) and/or catalase $\left(0.3 \mathrm{mg} \mathrm{m}^{-1}\right.$ ) were introduced to sequester $\mathrm{O}_{2}^{-}$or $\mathrm{H}_{2} \mathrm{O}_{2}$ respectively. Growth was assessed following a $7 \mathrm{~d}$ 'grow up', as measured by MTT reduction (optical density $620 \mathrm{~nm}$ ). Data are means $( \pm \mathrm{SE})$ of triplicate values

macrophages at any of the concentrations tested (Fig. 3), suggesting that nitric oxide radicals were not implicated in this event. At the highest concentration used there were indications that a toxic effect on $R$. salmoninarum cultured with the untreated macrophages was appearing, so no further increases in LNMMA concentration were tested.

Utilising a photochemical generation method, it was demonstrated that Renibacterium salmoninarum was susceptible to oxygen radical species. When bacteria were exposed to an activated riboflavin and methionine solution, a significant $(\mathrm{p}<0.001$ ) reduction in growth occurred across all bacterial concentrations tested compared with bacteria in HBSS alone (Fig. 4). This result was attributable to radical products released, as neither methionine nor riboflavin solutions showed individual effects in vitro (data not shown). Furthermore, when SOD and catalase were introduced jointly to break down $\mathrm{O}_{2}{ }^{-}$and $\mathrm{H}_{2} \mathrm{O}_{2}$, respectively, from this system, bacterial growth remained at levels that were not significantly different to the HBSS control. To elucidate whether one or both radical species were responsible for killing, each enzyme was added individually. The addition of SOD alone did not prevent significant $(p<0.001)$ growth inhibition from occurring. In contrast, catalase inclusion in vitro again retained bacterial growth at levels not significantly different to the HBSS control.

Examination of the respiratory burst activity of macrophages which had been exposed to Renibacterium salmoninarum for $3 \mathrm{~d}$ showed that there was a significant $(p<0.001)$ difference between control cells and MAF-treated cells across all bacterial concentrations tested (Fig. 5). Notably, the respiratory burst of untreated cells became exhausted using at least 2 doubling dilutions of bacteria before MAF-treated cells. Interestingly, the proportional difference in respiratory burst activity between MAF-treated and untreated cells increased in magnitude with increasing bacterial numbers (Fig. 5)

As greater respiratory burst activity in MAF-treated macrophages would potentially result in elevated $\mathrm{H}_{2} \mathrm{O}_{2}$ release in vitro, catalase was introduced into in vitro co-culture assays to determine if $\mathrm{H}_{2} \mathrm{O}_{2}$ was involved in MAF-mediated growth inhibition. The results of this experiment (Fig. 6) further demonstrate that MAF can mediate significant ( $\mathrm{p}<0.001)$ Renibacterium salmoninarum growth inhibition by macrophages, although the effect was not as dramatic as in Fig. 1 due to the use of a different batch of MAF super-

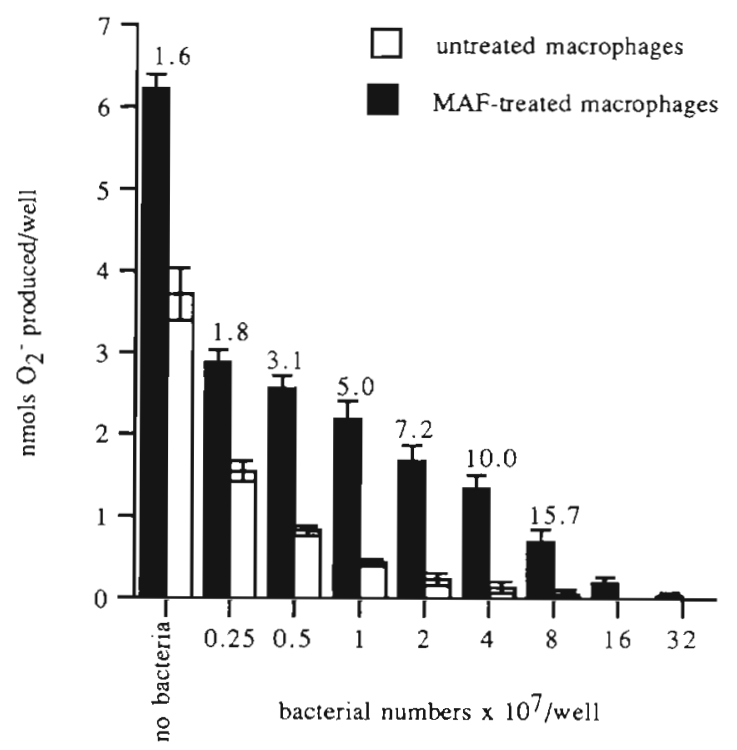

Fig. 5. Effect of exposure to varying concentrations of Renibacterium salmoninarum for $3 \mathrm{~d}$ on the respiratory burst of untreated or MAF-treated macrophages, assessed via the production of superoxide anion $\left(\mathrm{O}_{2}^{-}\right)$. Data are means $( \pm \mathrm{SE}$ ) of triplicate fish. The ratio of $\mathrm{O}_{2}^{-}$produced by MAF-treated and untreated macrophages is given above each bacterial concentration used 


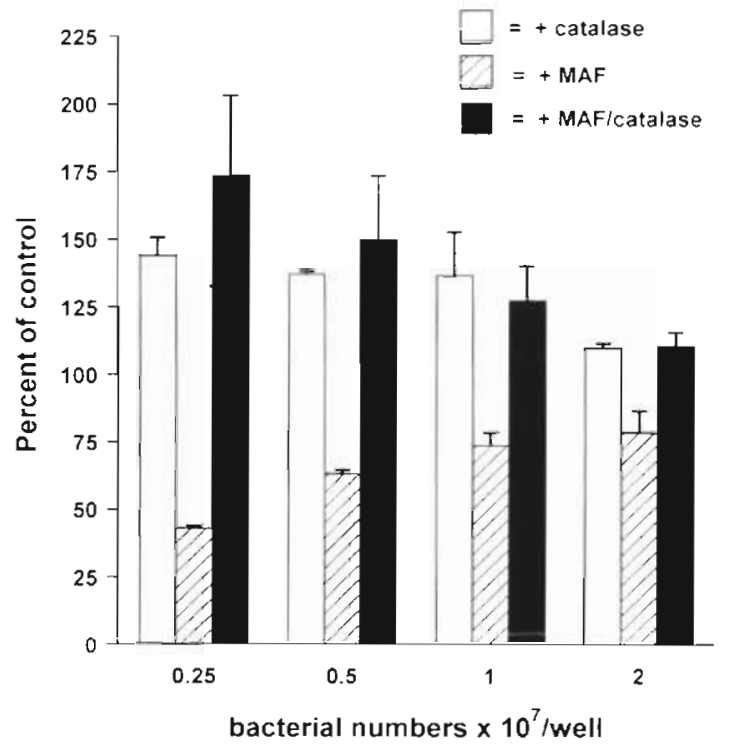

Fig. 6. Effect of catalase on Renibacterium salmoninarum growth inhibition when co-cultured for $7 \mathrm{~d}$ in vitro with untreated or MAF-treated macrophages, as measured by MTT reduction. Data are expressed as a percentage of the optical density values obtained with untreated macrophages in the absence of catalase, and are means $( \pm S E)$ of triplicate fish

natant. Introduction of catalase to untreated and MAFtreated macrophages significantly enhanced bacterial growth $(p<0.001)$ across all concentrations of bacteria tested. In addition, the significant difference in $R$. salmoninarum growth curves between control and MAF-treated macrophages was no longer present when catalase was introduced in vitro, suggesting that the enhanced growth inhibition of $R$. salmoninarum in response to MAF treatment is $\mathrm{H}_{2} \mathrm{O}_{2}$ dependent.

\section{DISCUSSION}

The results presented indicate that rainbow trout macrophages are capable of restricting Renibacterium salmoninarum growth when activated by appropriate cytokine stimulation in vitro, although whether the observed growth inhibition is due to a bactericidal or bacteriostatic mechanism is not clear and awaits further study. Growth of $R$. salmoninarum was not inhibited by untreated macrophages in the present study; indeed, growth was better supported by intact untreated macrophages compared with lysed macrophages, possibly as a result of microbicidal cytoplasmic products released when macrophages were lysed, or it could be that an intracellular microenvironment provided better conditions for growth. These findings contrast with the results of Bandin et al. (1992) who showed that untreated trout macrophages could acquire 'killing' activity when co-cultured for 5 or more days with $R$. salmoninarum. This apparent disparity may be resolved when experimental variables such as the level of macrophage activation in vivo prior to tissue culture or whether macrophages became nutritionally deprived in vitro, a factor shown to stimulate spontaneous activation in mammalian phagocytes (Walker et al. 1991), are considered. Nevertheless, cytokine-activated macrophages are clearly able to inhibit $R$. salmoninarum after co-culture for as little as $1 \mathrm{~d}$, which untreated macrophages cannot.

It appears that nitric oxide radical generation was not involved in the retardation of Renibacterium salmoninarum growth during the present study because the inclusion of L-NMMA at concentrations known to inhibit nitric oxide production in mammalian and fish studies (Liew \& Cox 1991, Wang et al. 1995) had no impact. Rather, upregulation of the respiratory burst appears to be responsible for $R$. salmoninarum 'killing' by these MAF-treated cells. This study and the results of Bandín et al. (1992) have shown that under non-activated conditions the respiratory burst of trout macrophages co-incubated with $R$. salmoninarum is usually compromised during the course of a $6 \mathrm{~d}$ in vitro infection, with maximal effects from Day 3 onwards. However, in the present study, MAF treatment elevated macrophage respiratory burst capacity during in vitro culture with $R$. salmoninarum. That $R$. salmoninarum was sensitive to $\mathrm{H}_{2} \mathrm{O}_{2}$ exposure in a cell-free system and that catalase abrogated growth inhibition during the in vitro macrophage assay suggests that MAF pretreatment permited adequate $\mathrm{H}_{2} \mathrm{O}_{2}$ generation by macrophages during the respiratory burst to check Renibacterium growth, and that this effect was likely to be a consequence of the bactericidal activity of $\mathrm{H}_{2} \mathrm{O}_{2}$ (Halliwell \& Gutteridge 1989). A trend to increased 'killing' was also seen in the cell-free system when SOD was included, presumably due to the increased $\mathrm{H}_{2} \mathrm{O}_{2}$ levels produced following dismutation of the generated superoxide anion. Although the 'killing' mechanism was $\mathrm{H}_{2} \mathrm{O}_{2}$ dependent, $\mathrm{H}_{2} \mathrm{O}_{2}$ derivatives such as hypohalides, hydroxyl or singlet oxygen species may also have been involved. The situation described above parallels findings with some intracellular pathogens of mammals such as Brucella abortus (Baldwin et al. 1993) and Cowdria ruminantium (Mahan et al. 1994).

An increased phagocytic uptake of Renibacterium salmoninarum by activated macrophages may also have contributed to this phenomenon since activated trout macrophages typically have an increased phagocytic uptake (Secombes \& Fletcher 1992). This scenario, however, assumes that killing of $R$. salmoninarum can only occur intracellularly in fish macrophages. Whilst precedents for this exist with Gram-negative 
fish bacterial pathogens such as Aeromonas salmonicida (Sharp \& Secombes 1992), no data are currently available for $R$. salmoninarum. Nevertheless, large numbers of $R$. salmoninarum have been shown to be phagocytosed by normal rainbow trout macrophages following co-cultivation for $24 \mathrm{~h}$ (Bandín et al. 1995). As normal macrophages have low or no inhibiting effect on $R$. salmoninarum growth, phagocytosis of $R$. salmoninarum per se does not appear to relate to killing.

Previous studies using Aeromonas salmonicida have shown that immunisation of trout can prime for MAF release following a subsequent exposure to the homologous antigen (Marsden et al. 1994). Whilst it is not known whether MAF release can be primed with Renibacterium salmoninarum, it is clear from this study that, following activation, salmonid macrophages have the capability to suppress or eliminate $R$. salmoninarum infection. So are there any reasons why this may not occur in vivo? Temperature may be one important factor. Outbreaks of BKD in rainbow trout and Atlantic salmon follow a seasonal pattern in Scotland, occurring between February and September, rising to a peak in May (Bruno 1986a). Indeed, recovery from the disease during experimental infections has been shown to be temperature dependent (Bruno 1986b, 1988). In Scotland, freshwater temperatures do not reach $10^{\circ} \mathrm{C}$ until early/mid May, and rise to about $14^{\circ} \mathrm{C}$ in June/July. Since fish primary $T$ cell responses, including production of MAF (Hardie et al. 1994a), are temperature sensitive (Bly \& Clem 1992), it is likely that immediately prior to $\mathrm{BKD}$ outbreaks rainbow trout would have a restricted MAF-producing capacity on first encounter with $R$. salmoninarum. As temperatures rise during May/June, it may be possible to elevate MAF production, permitting macrophages to become activated and contribute to the clearance of bacteria.

As rainbow trout have the immunological armoury to combat Renibacterium salmoninarum, it should be possible to design vaccines which mobilise these defences in an appropriate manner. In vivo, the immune system can activate different mechanisms for attacking and eliminating pathogens. It is known in mammalian studies that helper $\mathrm{T}$ cells $\left(\mathrm{T}_{H}\right)$ are required for both antibody and cell-mediated responses, and are composed of distinct subsets, distinguished by characteristic cytokine signatures (Del Prete \& Romagnani 1994). Thus, $T_{H} 1$ cells secrete IFN- $\gamma$, IL2 and TNF- $\beta$, whereas $\mathrm{T}_{\mathrm{H}} 2$ cells secrete IL4, IL5, IL6 and IL10. Formation of the appropriate $T_{H}$ subset is fundamental for the resolution of disease states in mammals, and determines whether a cell-mediated or humoral (antibody) immune response predominates (Johnson \& McMurray 1994, Surcel et al. 1994). Whilst virtually nothing is known about $T$ cell subsets in fish, their immune system is remarkably similar to that seen in other vertebrates (Faisal \& Hetrick 1992, Secombes 1994). Thus, by stimulating the equivalent of a $T_{H} 1$ like response in salmonids (i.e. cell-mediated immunity) resulting in MAF-stimulated macrophage inhibition of $R$. salmoninarum, it may be possible to induce protection. That antibody responses to various $R$. salmoninarum antigens are commonly not protective to the fish (Evelyn 1993) but indeed appear to promote the intracellular survival of the bacterium (Bandin et al. 1995), may indicate that $T_{H} 2$-like responses (i.e. humoral immunity) are being driven in many instances. Protection would not be elicited during a $\mathrm{T}_{\mathrm{H}}$ 2-like response because suitable factors such as IFN- $\gamma$ analogues (i.e. MAF) would not be available to activate macrophages. If $\mathrm{T}_{\mathrm{H}}$ subsets appropriate to $R$. salmoninarum were developed at permissive temperatures in salmonids, it would be expected that on restimulation by BKD infection, primed $\mathrm{T}$ cells would mount a MAF response at low environmental temperatures, with the potential to obviate spring outbreaks of BKD.

However, $\mathrm{T}_{H}$ subset development is governed by the nature of primary antigen encounter as this determines subsequent antigen processing and presentation. Macrophages exposed to high doses of live or fixed Mycobacterium bovis are provoked into 'exogenous' pathways of antigen presentation which bias $\mathrm{T}_{\mathrm{H}} 2$ development and $B$ cell activation (Griffin \& Buchan 1993). In contrast, recruitment of $T_{H} 1$ cells appears to be stimulated by endogenous processing of low doses of virulent or attenuated intracellular pathogens and IL12 signals from presenting macrophages (Bretscher 1992, Hsieh et al. 1993). These findings have prompted suggestions that cytokines, including IL2 and IFN- $\gamma$, could be used as immuno-adjuvants or immunostimulants to propel $T_{H} 1$ formation where appropriate. Since many intracellular bacteria exhibit phagosome dependent expression of certain genes (Plum \& Clark-Curtiss 1994) and intracellular growth is often a prerequisite to successful presentation and induction of $\mathrm{T}$-cell mediated immunity (Berche et al. 1987), it is possible that key Renibacterium salmoninarum antigens may not have been expressed during previous attempts to produce vaccines employing whole broth culture preparations and extractions (Evelyn 1993). Thus, more sophisticated approaches to the isolation and presentation of immunologically pertinent antigens may permit immunoprophylaxis against this widespread and economically important fish disease.

Acknowledgements. This work was supported by a grant from the Agriculture and Fisheries Research Council (No. AG $1 / 551$ ). 


\section{LITERATURE CITED}

Baldwin C, Jiang X, Fernandes DM (1993) Macrophage control of Brucellat abortus: influence of cytokines and iron. Trends Microbiol 1:99-104

Bandín I, Ellis AE, Barja JL, Secombes CJ (1992) Interaction between rainbow trout macrophages and Renibacterium salmoninarum in vitro. Fish Shellfish Immunol 3:25-33

Bandín I, Rivas C, Santos Y, Secombes CJ, Barja JL, Ellis AE (1995) Effect of serum factors on the survival of Renibacterium salmoninarum within rainbow trout macrophages. Dis Aquat Org 23:221-227

Baudin Laurencin F, Vigneulle M, Mevel M (1977) Premières observations sur la corynebactériose des salmonides en Bretagne. Bull Off Int Epizoot 87:505-507

Berche P, Gaillard JL, Sansonetti PJ (1987) Intracellular growth of Listeria monocytogenes as a prerequisite for in vivo induction of $\mathrm{T}$ cell-mediated immunity. J Immunol $138: 2266-2271$

Bly JE, Clem WL (1.992) Temperature and teleost immune functions. Fish Shellfish Immunol 2:159-171

Bretscher PA (1992) A strategy to improve the efficacy of vaccination agaiusi iuverculosis and ieprosy. Immunol Today 13:342-345

Bruno DW (1986a) Scottish experience with bacterial kidney disease in farmed salmonids between 1976 and 1985. Aquacult Fish Manage 17:185-190

Bruno DW (1986b) Histopathology of bacterial kidney disease in laboratory infected rainbow trout, Salmo gairdneri Richardson, and Atlantic salmon, Salmo salar L., with reference to naturally infected fish. J Fish Dis 9:523-537

Bruno DW (1988) The relationship between auto-agglutination, cell surface hydrophobicity and virulence of the fish pathogen Renibacterium salmoninarum. FEMS Microbiol Lett 51:135-140

Dannenberg AM Jr (1991) Delayed-type hypersensitivity and cell-mediated immunity in the pathogenesis of tuberculosis. Immunol Today 12:228-233

Del Prete G, Romagnani S (1994) The role of $\mathrm{TH}_{1}$ and $\mathrm{TH}_{2}$ subsets in human infectious diseases. Trends Microbiol 2: $4-6$

Denis $M$, Ghadirian E (1994) Interleukin-1 is involved in mouse resistance to Mycobacterium avium. Infect Immun 62:457-461

Ding AH, Nathan CF, Stuehr DJ (1988) Release of reactive nitrogen intermediates and reactive oxygen intermediates from mouse peritoneal macrophages. J Immunol 141: $2407-2412$

Evelyn TPT (1993) Bacterial kidney disease-BKD. In: Inglis V, Roberts RJ, Bromage NR (eds) Bacterial diseases of fish. Blackwell, Oxford, p 177-195

Faisal M, Hetrick FM (1992) Annual review of fish diseases, Vol 2. Pergamon Press, New York

Graham S, Jeffries AH, Secombes CJ (1988) A novel assay to detect macrophage bactericidal activity in fish: factors influencing the killing of Aeromonas salmonicida. J Fish Dis 11:389-396

Graham S, Secombes CJ (1988) The production of a macrophage-activating factor from rainbow trout Salmo gairdneri leucocytes. Immunology 65:293-297

Griffin JFT, Buchan GS (1993) Vaccination against tuberculosis: is BCG more sinned agaunst than sinner? Immunol Cel] Biol 71:431-442

Halliwell B, Gutteridge JMC (1989) Free radicals in biology and medicine, 2nd edn. Clarendon Press, Oxford

Hardie LJ, Fletcher TC, Secombes CJ (1994a) Effect of temperature on macrophage activation and the production of macrophage activating factor by rainbow trout (Oncorhynchus mykiss) leucocytes. Dev Comp Immunol 18 : $57-66$

Hardie LJ, Grabowski P, Ralston S, McGuigan F, Secombes CJ (1994b) Isolation of a partial coding sequence for nitric oxide synthase from rainbow trout macrophages. Dev Comp Immunol 18:88

Hsieh CS, Macatonia SE, Tripp CS, Wolf SF, O'Garra A, Murphy $\mathrm{K}$ (1993) Development of $\mathrm{TH}_{1} \mathrm{CD}^{+}{ }^{+} \mathrm{T}$-cells through IL-12 produced by Listeria induced macrophages. Science 260:547-549

Jang SI, Hardie LJ, Secombes CJ (1994) Effects of transforming growth factor $\beta_{1}$ on rainbow trout Oncorhynchus mykiss macrophage respiratory burst activity. Dev Comp Immunol 18:315-323

Johnson B, McMurray DN (1994) Cytokine gene expression by cultures of human lymphocytes with autologous Mycobacterium tuberculosis-infected monocytes. Infect Immun 62:1444-1450

Karczewski JM, Sharp GJE, Secombes CJ (1991) Susceptibility of strains of Aeromonas salmonicida to killing by cellfree generated superoxide anion. J Fish Dis 14:367-373

Kautmann SHE (1993) Immunity to intracellular bacteria A Rev Immunol 11:129-163

Liew FY, Cox FEG (1991) Nonspecific defence mechanism the role of nitric oxide. Immunol Today 12:A17-21

Liew FY, Li Y, Millott S (1990) Tumour necrosis factor (TNF $\alpha$ ) in leishmaniasis II. TNF $\alpha$-induced macrophage leishmanicidal activity is mediated by nitric oxide from L-arginine Immunology 71:556-559

Mahan SM, Smith GE, Byrom B (1994) Concanavalin Astimulated bovine T-cell supernatants inhibit growth of Cowdija ruminantium in bovine endothelial cells in vitro. Infect Immun 62:747-750

Marsden MJ, Cox D, Secombes CJ (1994) Antigen-induced release of macrophage activating factor from rainbow trout Oncorhynchus mykiss leucocytes. Vet Immunol Immunopathol 42:199-208

Nauciel C. Espinasse-Maes F (1992) Role of gamma interferon and tumour necrosis factor alpha in resistance to Salmo nella typhimurium infection. Infect Immun 60:450-454

Park J, Rikihisa Y (1992) L-arginine-dependent killing of intracellular Ehrlichia risticii by macrophages treated with gamma interferon. Infect Immun 60:3504-3508

Pick E (1986) Microassays for superoxide and hydrogen peroxide production and nitroblue tetrazolium reduction using an enzyme immunoassay microplate reader. Meth Enzymol 132:407-421

Plum G, Clark-Curtiss JE (1994) Induction of Mycobacterium avium gene expression following phagocytosis by human macrophages. Infect Immun 62:476-483

Rose AS, Levine RP (1992) Complement-mediated opsonisation and phagocytosis of Renibacterium salmoninarum. Fish Shellfish Immunol 2:223-240

Sandros J, Tuomanen E (1993) Attachment factors of Bordetella pertussis: mimicry of eukaryotic cell recognition molecules. Trends Microbiol 1:192-195

Schober A, Malz CR, Meyer DL (1993) Enzymehistochemical demonstration of nitric oxide synthase in the diencephalon of the rainbow trout (Oncorhynchus mykiss). Neurosci Lett 151:67-70

Schoor PW, Plumb JA (1994) Induction of nitric oxide synthase in channel catfish Ictalurus punctatus by Edwardsiella ictaluri. Dis Aquat Org 19:153-155

Secombes CJ (1990) Isolation of salmonid macrophages and analysis of their killing activity. In: Stolen JS, Fletcher TC, Anderson DP. Roberson. BS, van Muiswinkel WB (eds) 
Techniques in fish immunology, Vol 1. SOS Publications, Fair Haven, p 137-155

Secombes CJ (1994) Cellular defences of fish: an update. In: Pike AW, Lewis JW (eds) Parasitic diseases of fish. Samara Publishing Ltd, Tresaith, Dyfed, p 209-224

Secombes CJ, Fletcher TC (1992) The role of phagocytes in the protectuve mechanisms of fish. A Rev Fish Dis 2:53-71

Sharp GJE, Secombes CJ (1992) Observations on the killing of Aeromonas salmonicida by rainbow trout, Oncorhynchus mykiss (Walbauml macrophages. In: Shariff $M$, Subasinghe RP. Arthur JR (eds) Proc 1st Symp on Diseases in Asian Aquaculture. Fish Health Section, Asian Fisheries Society, p 379-389

Sharp GJE, Secombes CJ (1993) The role of reactive oxygen species in the killing of the bacterial fish pathogen Aeromonas salmonicida by rainbow trout macrophages. Fish Shellfish Immunol 3:119-129

Surcel HM, Troye-Blomberg $M$, Paulie S, Andersson G, Moreno C, Pasvol G, Ivanyi J (1994) Th1/Th2 profiles in

Responsible Subject Editor: D. Bruno, Aberdeen, Scotland, UK tuberculosis, based on the proliferation and cytokne response of blood lymphocytes to mycobacterial antigens. Immunology 81:171-176

Thomson AW (1991) The cytokıne handbook. Academic Press, London

Titus RG, Sherry B, Cerami A (1991) The involvement of TNF, IL-1 and IL-6 in the immune response to protozoan parasites. Immunol Today 12:A13-16

Walker L, Lowrie DB, Barclay R, Dixon G, Saunders K, Andrew PW (1991) Activation of mouse peritoneal macrophages by maintenance in serum-free medum. Immunology 73:109-113

Wang R, Neumann NF, Shen Q, Belosevic M (1995) Establishment and characterization of a macrophage cell line from the goldfish. Fish Shellfish Immunol 5:329-346

Young CL, Chapman GB (1978) Ultrastructural aspects of the causative agent and renal histopathology of bacterial kidney disease in brook trout (Salvelunus fontinalis). J Fish Res Bd Can 35:1234-1248

Manuscript first received: March 12, 1995

Revised version accepted: December 8, 1995 